Enrique Contreras Macía* Reyes Serrano Giménez* Ramón Morillo Verdugo*

\section{Prevalence of prescription of the Top-10 drug classes to avoid in elderly people living with HIV in a real practice cohort}

Servicio de Farmacia Hospitalaria, Hospital Universitario Virgen de Valme. Sevilla. Spain

\author{
Article history \\ Received: 1 August 2020; Revision Requested: 19 October 2020; Revision Received: 31 October 2020; \\ Accepted: 13 November 2020; Published: 30 December 2020
}

\section{ABSTRACT}

Objectives. We assessed the prevalence of potentially inappropriate prescriptions (PIP) among older ( $\geq 65$ years) people living with HIV (PLWHIV). Additionally, the secondary objective was to analyse the relationship between pharmacotherapeutic complexity and compliance with STOPP-Beers criteria associated with Top-10 drugs classes to avoid (TOP-10-A) of European AIDS Clinical Society (EACS) guidelines.

Methods. This was a cross-sectional observational single-centre study. PLWHIV aged 65 years-old or over on ART attending at pharmacy outpatient service of Hospital Universitario Virgen de Valme (Sevilla) from December-2019 to March-2020 were included. Patients were classified by age group: 65-69, 70-75 and more than 75 years. Moreover, was analysed the relationship between pharmacotherapeutic complexity and compliance with STOPP-Beers Criteria associated with Top-10-A drugs.

Results. A total of 19 individuals were included. Overall polypharmacy was observed in 16 PLWHIV (84.2\%). A PIP included Top-10-A was identified in 9 (47.4\%) PLWHIV. Benzodiazepines were the most prevalent group of prescribed drugs in 6 patients (30.0\%). Complex patients were observed in 57.9\% ( $\mathrm{MRCl}$ index value greater than 11.25). Similarly, the sum of criteria STOPP-Beers was higher in older patients. Student's t test showed the existence of a statistically significant relationship between pharmacotherapeutic complexity and sum of STOPP-Beers Criteria $(p<0.05)$ in elderly PLWHIV.

Conclusions. Prescription of PIPs is highly prevalent in older PLWHIV. Consistent with data, presence of PIPs were as-

\section{Correspondence:}

Enrique Contreras Macias

Servicio de Farmacia Hospitalaria, Hospital Universitario Virgen de Valme. Ctra. De Cádiz Km.

548,9. 41041. Sevilla. Spain

Phone: +35955015467

E-mail: enrique.contreras.macias.sspa@juntadeandalucia.es

*These authors have contributed equally to the work. sociated a presence of higher pharmacotherapeutic complexity and sum of STOPP-Beers Criteria. The basis for a new revised care plan for PLWHIV focussed on optimising overall patient care pharmacotherapeutic complexity and its possible consequences.

Keywords: HIV; ageing; polypharmacy.

Prevalencia de prescripción del Top-10 clases de fármacos a evitar en pacientes VIH de edad avanzada en una cohorte de práctica clínica real

\section{RESUMEN}

Objetivos. Evaluamos la prevalencia de prescripciones potencialmente inapropiadas (PIP) entre las personas mayores ( $\geq 65$ años) que viven con el VIH (PWIH). Además, el objetivo secundario fue analizar la relación entre la complejidad farmacoterapéutica y el cumplimiento de los criterios STOPP-BEERS asociados con las clases de medicamentos Top-10 para evitar (TOP-10-A) de las directrices de la Sociedad Europea de SIDA Clínica (EACS).

Métodos. Este fue un estudio transversal observacional de un solo centro. Las personas que viven con el VIH de 65 años o más en tratamiento antirretrovírico que asisten al servicio ambulatorio de farmacia del Hospital Universitario Virgen de Valme (Sevilla). Se incluyeron de diciembre de 2019 a marzo de 2020. Los pacientes fueron clasificados por grupo de edad: $65-69,70-75$ y más de 75 años. Además, se analizó la relación entre la complejidad farmacoterapéutica y el cumplimiento de los criterios STOPP-Beers asociados con los medicamentos Top-10-A.

Resultados. Se incluyeron un total de 19 individuos. Se observó polifarmacia general en 16 PWIH (84,2\%). Un PIP incluido Top-10-A fue identificado en $9(47,4 \%)$ PWS. Las benzodiacepinas fueron el grupo más frecuente de medicamen- 
tos recetados en 6 pacientes $(30,0 \%)$. Se observaron pacientes complejos en 57,9\% (valor del indice MRCl mayor que 11,25). Del mismo modo, la suma de criterios STOPP-Beers fue mayor en pacientes de edad avanzada. Se observó la existencia de una relación estadisticamente significativa entre la complejidad farmacoterapéutica y la suma de los Criterios STOPP-Beers ( $p$ $<0,05)$ en PWIH de edad avanzada.

Conclusiones. La prescripción de PIP es altamente prevalente en las personas que viven con el VIH de mayor edad. De acuerdo con los datos, la presencia de PIP se asoció con una mayor complejidad farmacoterapéutica y la suma de los criterios STOPP-Beers. La base para un nuevo plan de atención revisado para PWIH se centró en optimizar la complejidad farmacoterapéutica general de la atención al paciente y sus posibles consecuencias.

Palabras clave: VIH; envejecimiento, polifarmacia.

\section{INTRODUCTION}

Over the last four decades people living with HIV (PLWHIV) have raised their life expectancy thanks to antiretroviral treatment (ART) [1]. This successful challenge has resulted in clinical services now attending an older HIV-cohort, with patients experiencing many of the problems of an old HIV-negative cohort such as multiple medical diagnoses, comorbidities and frailty [2]. The progressive aging of our patients leads to an increase of polypharmacy, increasing the risk of adverse events, drug interactions and potentially inappropriate prescriptions (PIP) [3].

Annually, the European AIDS Clinical Society (EACS) publishes a scientific guideline whose goal is to provide comprehensive and easily accessible recommendations to clinicians involved in the care of PLWHIV. In 2019, the EACS guideline included for first time a "Selected Top 10 Drug Classes To Avoid (Top-10-A) in elderly PLWHIV" because of the problems they could cause to this population. The list included first generation antihistamines, tricyclic antidepressants, benzodiazepines, atypical antipsychotics, urological spasmolytic agents, stimulant laxatives, nonsteroidal anti-inflammatory drugs, digoxin, long acting sulfonylureas and cold medications [4].

Due to this, one of the most important pending challenges for the future is to adapt a multidisciplinary methodology to the needs of the multidimensional approach needed on PLWHIV, especially those with greater pharmacotherapeutic complexity, who may have a higher risk of non-adherence, hospital readmissions and worse health outcomes. For this reason, it is necessary to incorporate new concepts and strategies of joint work to carry out multidimensional interventions [5-7].

The main objective of this study was to determine the prevalence of prescription drugs included in Top-10-A of the EACS-2019 guideline in PLWHIV elderly patients in a real clinical practice cohort. Additionally, the secondary objective was to analyze the relationship between pharmacotherapeutic complexity and compliance with STOPP-Beers criteria associated with Top-10-A drugs.

\section{METHODS}

This was a cross-sectional observational single-center study. PLWHIV aged 65 years-old or over on ART attending at hospital pharmacy outpatient service from December-2019 to March-2020 were included. Those patients received the pharmacotherapeutic follow-up already routinely applied to ambulatory care patients according to a CMO pharmaceutical care model [8]. Patients were excluded if they were participating in a clinical trial or did not give their written informed consent.

The study fulfilled all the ethical requirements and was approved by the Clinical Research Ethics Committee of Sevilla-Sur (code 1420-n-20).

The following variables were analyzed: demographic (age, sex); analytical data, plasma viral load (copies/mL), CD4 cell count (cells $/ \mu \mathrm{L}$ ); and clinical variables related to comorbidities and pharmacotherapeutics, such as type of ART, concomitant medications, presence of polypharmacy and presence of drugs included in Top-10-A. Only those patients with all variables completed were included in the analysis.

Patients were classified by age group: 65-69, 70-75 and more than 75 years. Data was obtained from the medical record, electronic prescription program, and outpatient dispensing program. Additionally, the secondary objective was to analyze the relationship between pharmacotherapeutic complexity (according to Medication Regimen Complexity Index) [9] and compliance with STOPP-Beers criteria associated with Top-10-A. Moreover, according to Morillo-Verdugo et al. [10] a cut-off value of 11.25 for MRCl index score was employed for considering complex patient. To facilitate the determination of the relationship between $\mathrm{MRCl}$ and presence of STOPP-Beers Criteria, the sum of both criteria was performed.

Discrete variables were expressed as counts (percentage) and continuous variables as medians and interquartile ranges (IQRs) or means and standard deviation (SD). An inferential analysis was performed using the T-Student test. The threshold for statistical significance was defined as $p<0.05$. Data analysis was performed using SPSS for Windows 25.0.0 (SPSS, Chicago, IL, USA).

\section{RESULTS}

A total of 19 patients were included in this study, mean age of $69.4 \pm 5.4$ years, $68.4 \%$ males. Globally, the number of patients stratified according to the CMO pharmaceutical care model were 12 in level $3(63.2 \%)$, 4 in level $2(20 \%)$ and 3 in level 1 (15.8\%). Their demographicaps, clinics, pharmacoterapeutics and pharmaceutical care characteristics were collected in Table 1.

According to the classification groups established by age, the number of patients classified in 65-70 years group were 13, 3 in 70-75 years group and 3 in more than 75 years group. Overall, a number of concomitant drugs was higher in patients more than 75 years $(13.1 \pm 2.5)$ compared to $70-75$ years $(7.6 \pm 3)$ and $65-69$ years group $(5.7 \pm 2.6)(p=0.001)$. Moreover, 


\begin{tabular}{|c|c|c|}
\hline \multirow[t]{3}{*}{ Table 1} & \multicolumn{2}{|c|}{$\begin{array}{l}\text { Baseline demographics, clinics, } \\
\text { pharmacotherapeutics and } \\
\text { pharmaceutical care characteristics }\end{array}$} \\
\hline & & Total cohort \\
\hline & & $N=19$ \\
\hline \multicolumn{3}{|c|}{ Demographics } \\
\hline \multicolumn{2}{|c|}{ Age (years) Mean \pm SD } & $69.4 \pm 5.4$ \\
\hline \multicolumn{2}{|c|}{ Gender (Male) n (\%) } & $13(68.4)$ \\
\hline \multicolumn{2}{|c|}{ CDC classification (aids) } & $6(31.6)$ \\
\hline \multicolumn{3}{|l|}{ Clinics } \\
\hline \multicolumn{2}{|c|}{ CD4 level (> 200 cels $/ \mathrm{mL})$} & $17(89.5)$ \\
\hline \multicolumn{2}{|c|}{ Undetectable viral load (<50 c/mL) } & $18(94.7)$ \\
\hline \multicolumn{3}{|c|}{ Pharmacotherapeutics } \\
\hline \multicolumn{3}{|l|}{ ART type* } \\
\hline \multicolumn{2}{|c|}{ ITIAN + ITINN } & $0(0)$ \\
\hline \multicolumn{2}{|c|}{ ITIAN + Inin } & $9(45.0)$ \\
\hline \multicolumn{2}{|c|}{ ITIAN + IP } & $4(25.0)$ \\
\hline \multicolumn{2}{|c|}{ 0thers ${ }^{* *}$} & $6(30.0)$ \\
\hline \multicolumn{2}{|c|}{ Concomitant medication. Mean \pm SD } & $6.8 \pm 5.5$ \\
\hline \multicolumn{2}{|c|}{ Polymedicated n (\%) } & $16(84.2)$ \\
\hline \multicolumn{2}{|c|}{$\mathrm{MRCl}^{* * *}$ (points). Mean \pm SD } & $11.9 \pm 5.8$ \\
\hline \multicolumn{3}{|c|}{ Pharmaceutical care } \\
\hline \multicolumn{2}{|c|}{ Beers Criteria. Median (IOR) } & $1(0-6)$ \\
\hline \multicolumn{2}{|c|}{ STOPP Criteria. Median (IOR) } & $1(0-3)$ \\
\hline \multicolumn{3}{|c|}{ Stratification ***a } \\
\hline \multicolumn{2}{|l|}{ N3 } & $12(63.2)$ \\
\hline \multicolumn{2}{|l|}{ N2 } & $4(20)$ \\
\hline \multicolumn{2}{|l|}{ N1 } & $3(15.8)$ \\
\hline
\end{tabular}

*ART. Antiretroviral therapy; ${ }^{* *} 0$ thers include all ART regimens without ITIAN; ${ }^{* *} \mathrm{MRCl}$ denotes medication regimen complexity Index; ${ }^{* * *}$ Stratification according Spanish Society of Hospital Pharmacy.

${ }^{a}$ Distribution of $\mathrm{MRCl}$ according to stratification $[\mathrm{N} 3,9.8 \pm 4.6$; $\mathrm{N} 2,15.1 \pm 4.1$; $N 1,19.6 \pm 6.4 ;$ ANOVA $\left.P_{\text {intergroups }}<0.001\right]$

9 of the 19 patients (47.4\%) had medication included in the Top-10-A. Benzodiazepines were the most prevalent group of prescribed drugs included in 6 patients (30.0\%), followed by nonsteroidal anti-inflammatory drugs (11.1\%), urological spasmolytic agents (5.6\%), digoxin (5.6\%) and first generation antihistamines (5.6\%).

Regarding one of the main variables, the $\mathrm{MRCl}$ index mean was $11.9 \pm 5.8$, complex patients in $57.9 \%(\mathrm{MRCl}$ index value greater than 11.25). Additionally, $\mathrm{MRCl}$ index was higher for patients classified in more than 75 years group (22.8 \pm 2.1$)$ compared to $70-75$ years $(14.7 \pm 6.5)$ and $65-70$ years group $(9.9 \pm 3.4)(p=0.003)$. The other main variable includes the sum of STOPP-Beers criteria. As in the $\mathrm{MRCl}$ value, the sum of the criteria was higher for patients of higher age group: patients $>75$ years $(4.4 \pm 2.1), 70-75$ years $(3.2 \pm 2.6)$ and $65-69$ years $(2.1 \pm 1.7)(p<0.001)$. Figure 1 shows the relationship of the $\mathrm{MRCl}$ value and sum of STOPP-Beers criteria by age group and the results of statistical test.

More than $50 \%$ of these criteria were associated with the prescription of drugs included Top-10-A, fundamentally benzodiazepines.

\section{DISCUSSION}

In the present study, we found a high overall frequency of prescription of the drugs included in Top-10-A in our population. Moreover, high $\mathrm{MRCl}$ values in older people with HIV are related to an increased presence of STOPP-Beers Criteria. Finally, the statistical relationship shows how there is a greater sum of the values of the STOPP-Beers criteria as the $\mathrm{MRCl}$ values increase.

To our knowledge, this is the first study that clearly correlates pharmacotherapeutic complexity with presence of STOPP-Beers criteria in elderly PLWHIV. Previous studies observed that HIV-infected older adults were polymedicated, where more than 50\% were PIP, including Top-10-A drugs [11]. Furthermore, Tseng et al. [12] showed the association between aging and polypharmacy with the consequent increase in the risk of interactions with ART, particularly cardiovascular agents such as digoxin, included in Top-10-A. Because of polypharmacy is associated with increase in drug-related morbidity and mortality from adverse events and drug interactions, identifying patients with polypharmacy is relevant. In addition, identifying patients with PIP is important due to an increased risk of drug interactions by $85.0 \%$ [13].

A serie of tools used to detect and prevent the use of PIP among older adults of the general population include the Beers criteria for inappropriate medication use in older adults [14] and Screening Tool of Older Persons' Prescription (STOPP) [11]. Due to patient aging, there is an increasing percentage of polymedicated patients with the inherent risks already mentioned, which has increased interest in this area. McNicholl et al. [15] showed a statistically significant relationship between polypharmacy and the presence of STOPP-Beers criteria. However, the concept of polypharmacy only takes into account the number of prescribed medication without considering the complexity of the pharmacotherapeutic regimen. For this reason, we have used the $\mathrm{MRCl}$ index, which is a validated tool that evaluates treatment regimen complexity based on the number of medications, dosage form, dosage frequency, and additional or special instructions. This tool allows us to know the impact of the pharmacotherapeutic regimen and its possible relationship with the development of drug-drug interactions and adverse events described in STOPP-Beers criteria.

Despite the statistically significant results, we proposed as a proof of concept study to demonstrate the importance of polypharmacy in older PLWHIV. It is a good initial approach for this problem, but due to the need to face this 


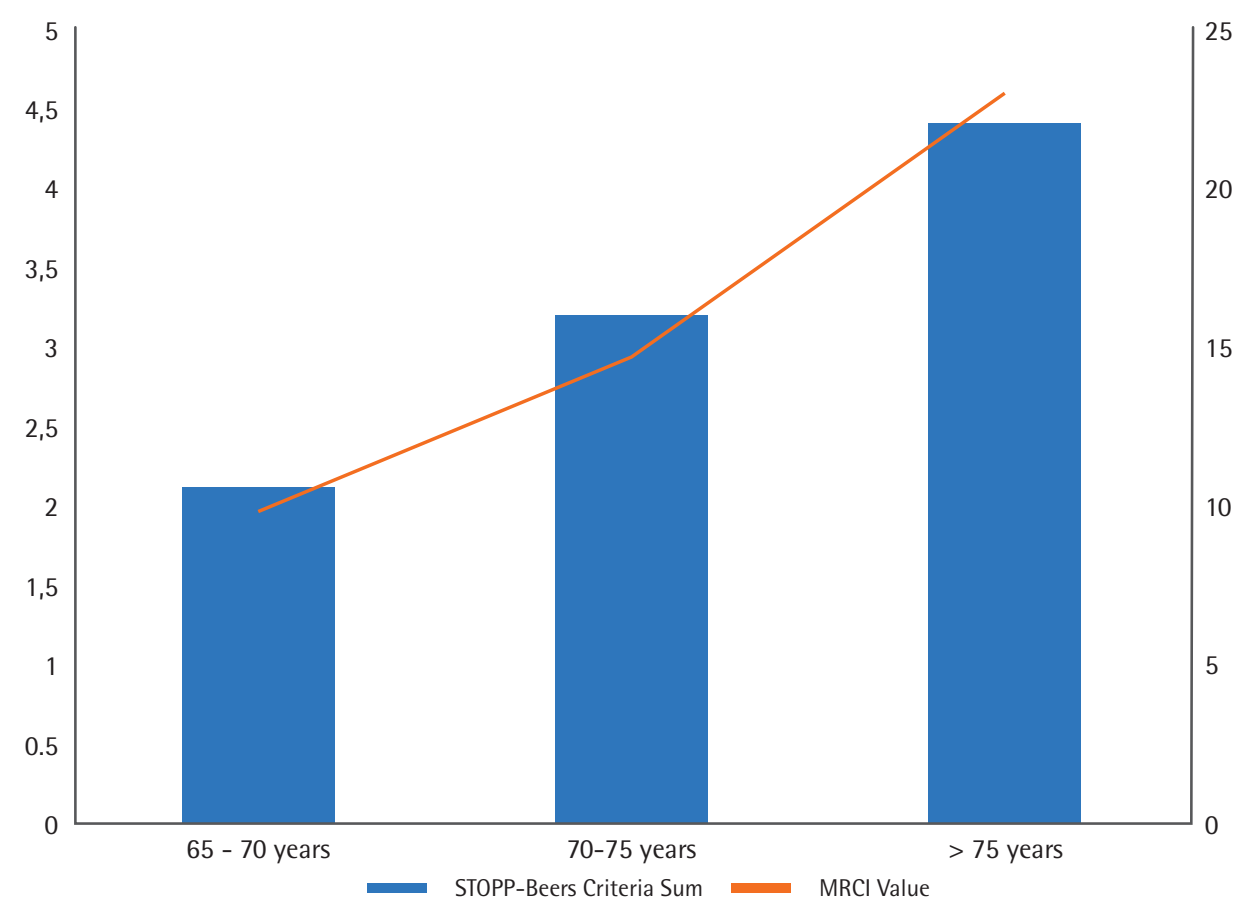

Figure $1 \quad$ Relationship of the MRCI value and sum of STOPP-Beers criteria by age group.The analysis using Student's T test showed the existence of statistically significant relationship between variables $(p<0.05)$.

challenge, a multicenter study is being carried out to obtain results that facilitate the development of strategies, such as deprescription, to improve the pharmacotherapeutic strategies of PLWHIV.

The present study may have some limitations. First, our study was based on a single urban safety net hospital, so generalizability to other settings and patient population would be a priority. Moreover, the sample size was reduced and this makes the results may not apply to hospitals. On the other hand, STOPP-Beers criteria were validated to patients $\geq 65$ years non HIV-infected. Despite these potential limitations, this study has successfully identified the correlation between $\mathrm{MRCl}$ and these criteria. HIV specialist interventions should be carried out more frequently and intensively in current patients, with a methodology that takes into account their needs and individual characteristics and not focused on the prescribed medication, stressing the importance of an effective patient care model to closely monitor high risk-patients.

In conclusion, the results of our study form the basis for a new revised care plan for PLWHIV focused on optimising overall patient care, not only limited to viral load goal achievement but also in their pharmacotherapeutic complexity and its possible consequences. No doubt, not only multidisciplinary, but also multidimensionally would be the most successful to approach PLWHIV in the near future.

\section{FUNDING}

None to declare.

\section{CONFLICTS OF INTEREST}

The authors declare that they have no conflict of interest.

\section{REFERENCES}

1. Cahill S, Valadez R. Growing older with HIV/AIDS: new public health challenges. Am J Public Health. 2013;103(3):e7-e15. doi:10.2105/ AJPH.2012.301161.

2. Smit $M$, Brinkman $K_{1}$ Geerlings $S$, et al. Future challenges for clinical care of an ageing population infected with HIV: a modelling study [published correction appears in Lancet Infect Dis. 2015 Sep;15(9):998]. Lancet Infect Dis. 2015;15(7):810-818. doi:10.1016/S1473-3099(15)00056-0.

3. Edelman EJ, Gordon KS, Glover J, McNicholl IR, Fiellin DA, Justice AC. The next therapeutic challenge in HIV: Polypharmacy. Drugs Aging. 2013;30:613-28. doi: 10.1007/s40266-013-0093-9.

4. European AIDS Clinical Society (EACS) guidelines [cited 2020 Jun 16]. Available from: https://www.eacsociety.org/files/2019_guidelines-10.0_final.pdf

5. Guaraldi G, Orlando G, Zona S, Menozzi M, Carli F, Garlassi C et 
al. Premature Age-Related Comorbidities Among HIV-Infected Persons Compared With the General Population. Clin Infect Dis; 2011(53): 1120-1126. doi: 10.1093/cid/cir627.

6. Marzolini C, Elzi L, Gibbons S, Weber R, Fux C, Furrer H et al. Prevalence of comedications and effect of potential drug-drug interactions in the Swiss HIV Cohort Study. Antivir Ther. 2010;15(3):41323. doi: 10.3851/IMP1540.

7. Guaraldi G, Malagoli A, Calcagno A, Mussi C, Celesia BM, Carli F, Piconi S, De Socio GV, Cattelan AM, Orofino G, Riva A, Foca E, Nozza S, Di Perri G (2018) The increasing burden and complexity of multi-morbidity and polypharmacy in geriatric HIV patients: a cross sectional study of people aged $65-74$ years and more than 75 years. BMC Geriatr 18 (1): 99 doi 10.1186/s12877-018-0789-0.

8. Morillo-Verdugo $R$, Martínez-Sesmero JM, Lázaro-López $A$, Sánchez-Rubio J, Navarro-Aznárez $H_{1}$ DeMiguel-Cascón M. Development of a risk stratification model for pharmaceutical care in HIV patients. Farm Hosp. 2017;41(3):346-356. doi: 10.7399/ fh.2017.41.3.10655.

9. Alves-Conceição V, Rocha KSS, Silva FVN, et al. Are Clinical Outcomes Associated With Medication Regimen Complexity? A Systematic Review and Meta-analysis. Ann Pharmacother. 2020;54(4):301-313. doi:10.1177/1060028019886846

10. Morillo-Verdugo $R$, Robustillo-Cortés MA, Abdel-Kader Martín $L_{\text {, }}$ Álvarez de Sotomayor Paz M, Lozano de León Naranjo F, Almeida González CV. Determination of a Cutoff Value for Medication Regimen Complexity Index to Predict Polypharmacy in HIV+ Older Patient. Rev Esp Quimioter. 2019;32(5):458-464. PMID: 31528986.

11. Greene M, Steinman MA, McNicholl IR, Valcour V. Polypharmacy, drug-drug interactions, and potentially inappropriate medications in older adults with human immunodeficiency virus infection. J Am Geriatr Soc. 2014;62(3):447-453. doi:10.1111/jgs.12695.

12. Tseng A, Szadkowski L, Walmsley S, Salit I, Raboud J. Association of age with polypharmacy and risk of drug interactions with antiretroviral medications in HIV-positive patients. Ann Pharmacother. 2013;47(11):1429-1439. doi: 10.1177/1060028013504075.

13. Hill-Taylor B, Sketris I, Hayden J, Byrne S, O'Sullivan D, Christie R. Application of the STOPP/START criteria: a systematic review of the prevalence of potentially inappropriate prescribing in older adults, and evidence of clinical, humanistic and economic impact. J Clin Pharm Ther. 2013;38(5):360-372. doi: 10.1111/jcpt.12059.

14. By the American Geriatrics Society Beers Criteria Update Expert $P$ (2015) American Geriatrics Society 2015 updated Beers criteria for potentially inappropriate medication use in older adults. J Am Geriatr Soc 63(11):2227-2246. doi: 10.1111/jgs. 13702.

15. McNicholl IR, Gandhi M, Hare CB, Greene M, Pierluissi E. A Pharmacist-Led Program to Evaluate and Reduce Polypharmacy and Potentially Inappropriate Prescribing in Older HIV-Positive Patients. Pharmacotherapy. 2017;37(12):1498-1506. doi: 10.1002/ phar.2043. 